\title{
Chikungunya fever in two German tourists returning from the Maldives, September, 2009
}

M Pfeffer (pfeffer@vetmed.uni-leipzig.de) ${ }^{1}$, I Hanus², T Löscher ${ }^{2}$, T Homeier $^{1}$, G Dobler ${ }^{3}$

1. Institute of Animal Hygiene and Veterinary Public Health, Veterinary Faculty, University of Leipzig, Germany

2. Department of Infectious Diseases and Tropical Medicine, University of Munich, Munich, Germany

3. Bundeswehr Institute of Microbiology, Munich, Germany

Citation style for this article:

Citation style for this article: Pfeffer M, Hanus I, Löscher T, Homeier T, Dobler G. Chikungunya fever in two German tourists returning from the Maldives, September, 2009. Euro Surveill. 2010;15(13):pii=19531. Available online: http://www.eurosurveillance.org/ViewArticle.aspx?Articleld=19531

This article has been published on 1 April 2010

This report describes the first isolation and molecular characterisation of a chikungunya virus from two German tourists who became ill after a visit to the Maldives in September 2009. The virus contained the $\mathrm{E}_{1} \mathrm{~A} 226 \mathrm{~V}$ mutation, shown to be responsible for an adaptation to the Asian tiger mosquito Aedes albopictus. The E1 coding sequence was identical to chikungunya virus isolates from Sri Lanka and showed three nt-mismatches to the only available E1 nt sequence from the Maldives.

\section{Introduction}

Since the start of the current chikungunya fever pandemic on the east coast of Africa in 2005, many cases have been reported in countries in Asia and south-east Asia $[1,2]$. These cases were attributed to a particular chikungunya virus (CHIKV) strain that has adapted to very efficient transmission to humans via the Asian tiger mosquito (Aedes albopictius) due to a A226V mutation in the E1 envelope protein $[3,4]$. The Maldives were first hit by the chikungunya virus pandemic in late 2006 after the wet season which usually lasts until September. Based on almost 12,000 suspected cases of chikungunya fever the disease was reported on 121 of the 197 inhabited islands with incidence rates between 82 and 722 per 1,000 population [5]. A small set of blood samples from febrile patients with symptoms meeting the chikungunya fever case definition at that time confirmed CHIKV as causative agent in 64 of 67 cases by reverse-transcription PCR (RT-PCR) [5]. However, no further characterisation of the virus strain responsible for the 2006-7 outbreak was performed. One case of a traveller returning to Singapore in January 2007 was confirmed by RT-PCR and the nt sequence of the $E_{1}$ gene was determined [6]. In early 2009, an outbreak of a viral fever with symptoms including myalgia or arthralgia and rash occurred on several islands of the Laamu Atoll about $400 \mathrm{~km}$ south of Malé [7], but no further virological investigation was carried out to determine whether this was due to dengue or chikungunya fever.

\section{Case report and laboratory findings}

Between 1 and 10 September 2009, a German couple visited the Dhiffushi Holiday Island resort at the southern tip of the Ari Atoll, the Maldives (Figure 1), together with their seven year-old son. They flew directly from Munich to Malé with a stopover in Dubai, United Arab Emirates.

Two and three days respectively after the family had returned to Munich, the son and the 35 year-old father developed symptoms compatible with either dengue or chikungunya fever (Table) while the wife stayed healthy. A test for dengue virus showed neither virus RNA nor anti-dengue virus (DENV) IgM for both patients, but the father had IgG antibodies reactive against DENV indicating an earlier anamnestic dengue fever or a cross-reaction with an earlier flavivirus vaccination. CHIKV-specific real-time RT-PCR yielded ct-values of 23 (son) and 22.5 (father) in the respective acute serum samples obtained on 14 September, indicating high-level viremia $[8,9]$. Chikungunya virus was isolated in Vero B4 cells from both sera and the entire nucleotide sequence of the isolate from the father was determined. The viral genome was 11,811 nucleotides in length and showed high levels of identity with the pandemic CHIKV that is circulating in many parts of the Indian subcontinent and other parts of Asia since 2006. Most interestingly the CHIKV isolate from the Maldives contained the A226V change in the E1 glycoprotein which has been shown to be responsible for shorter extrinsic incubation periods in Aedes albopictus mosquitoes [4]. While the son made an uneventful recovery after one week of symptoms, the father developed persisting arthralgias with limited mobility in the affected extremities and still requires analgesic treatment (Table).

\section{Discussion}

Together with a very recent report on chikungunya fever in a French traveller returning from the northern part of Malé Island, Maldives, in October 2009 [10], our findings suggest a continuous circulation of CHIKV also in other parts of the Maldives. The family stayed 
on Dhiffushi Holiday Island throughout their holidays with a daytrip to the neighboring Sun Island. Malé with its international airport was only visited for the intercontinental flight connection, leaving not much time to become exposed to mosquito bites. We cannot rule out that both infections were acquired while waiting at the airport, because this would fit well with both the incubation period of the disease and with the previous case

\section{FIGURE 1}

Location of Holiday and Sun Islands on the southernmost rim of the south Ari Atoll, about $100 \mathrm{~km}$ away from Male International Airport

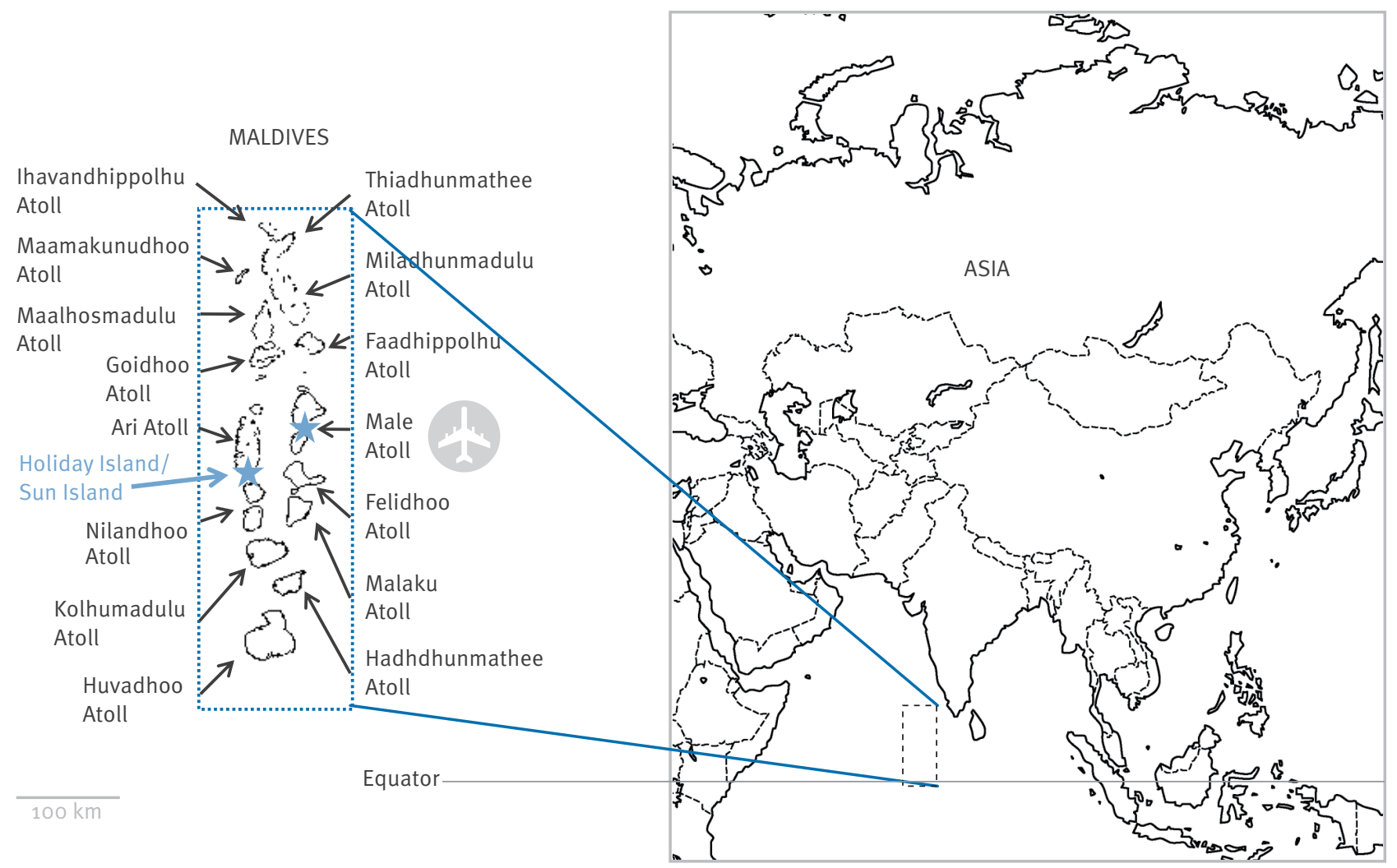

TABLE

Clinical and laboratory data of patients diagnosed with chikungunya fever, Germany, September 2009

\begin{tabular}{|c|c|c|}
\hline Patient & Son (7 years) & Father (35 years) \\
\hline Travel schedule & $\begin{array}{l}\text { Munich-Dubai-Male and back on 1-10 Septem- } \\
\text { ber, } 2009\end{array}$ & $\begin{array}{l}\text { Munich-Dubai-Male and back on 1-10 September, } \\
\qquad 2009\end{array}$ \\
\hline Onset of disease & 12 September 2009 & 13 September 2009 \\
\hline \multirow[t]{3}{*}{ Clinical presentation } & Fever $39.5^{\circ} \mathrm{C}$ & Fever $39.0^{\circ} \mathrm{C}$ \\
\hline & Headache & $\begin{array}{l}\text { Ague, retrobulbar pressure and pain, arthritis of } \\
\text { both wrists and ankles }\end{array}$ \\
\hline & $\begin{array}{c}\text { Macular and partially confluent exanthema } \\
\text { (mainly on face and torso) }\end{array}$ & $\begin{array}{l}\text { Erythema, macular and partially confluent exan- } \\
\text { thema (mainly on torso and arms) }\end{array}$ \\
\hline \multirow[t]{3}{*}{ Laboratory findings } & $\begin{array}{l}\text { Leucocytes } 2,700 / \mu \mathrm{l} \\
\text { CRP } 2.5 \mathrm{mg} / \mathrm{dl}\end{array}$ & $\begin{array}{c}\text { Leucocytes } 5,300 / \mu \mathrm{l} \\
\text { CRP } 13 \mathrm{mg} / \mathrm{dl} \\
\text { Creatinine } 1.4 \mathrm{mg} / \mathrm{dl}\end{array}$ \\
\hline & CHIKV RT-PCR positive & CHIKV RT-PCR positive \\
\hline & DENV RT-PCR negative & DENV-PCR negative; anti-DENV IgG 15E \\
\hline Therapy & Paracetamol, Ibuprofen & Paracetamol, Ibuprofen \\
\hline Further course & $\begin{array}{l}\text { Since } 16 \text { September fever-free, exanthema } \\
\text { gone on } 17 \text { September, no further complica- } \\
\text { tions since then }\end{array}$ & $\begin{array}{l}\text { Since } 16 \text { September fever-free and creatinin } \\
\text { back to normal }(1.1 \mathrm{mg} / \mathrm{dl}) \text {, exanthema gone, but } \\
\text { arthralgias of ankles, wrists, and digital joints } \\
\text { persist for more than six months including lim- } \\
\text { ited mobility and requiring NSAID treatment }\end{array}$ \\
\hline
\end{tabular}

CRP: C-reactive protein; CHIKV: Chikungunya virus; DENV: Dengue virus; RT-PCR: reverse transcription-polymerase chain reaction; NSAID: non steroidal anti-inflammatory drugs 
report of the French traveller, who became infected while staying at the Male Atoll. However, given the high incidence rates of 65.2 per 1,000 population previously reported for the Ari Atoll [5], both infections could likewise have been acquired on Holiday Island. Further, a considerable number of people travel constantly between India and Sri Lanka and the tourist resorts on the Atolls' islands of the Maldives where they are employed. This frequent exchange may argue for a repeated and renewed introduction of CHIKV from India or Sri Lanka via viraemic workers or tourists and limited local transmission through aedine mosquitoes at the respective islands. Analyses of the $\mathrm{E}_{1}$ gene revealed three nt-mismatches when compared to the 2007 case that was analysed in Singapore [6], but identical nt sequences to a series of CHIKV strains from Sri Lanka (Figure 2) [6,11].

\section{FIGURE 2}

Phylogenetic relationship generated by Maximum Parsimony method as implemented in MEGA4 based on the complete E1 protein coding sequence (1314 nt) of a set of CHIKV of different geographic origin

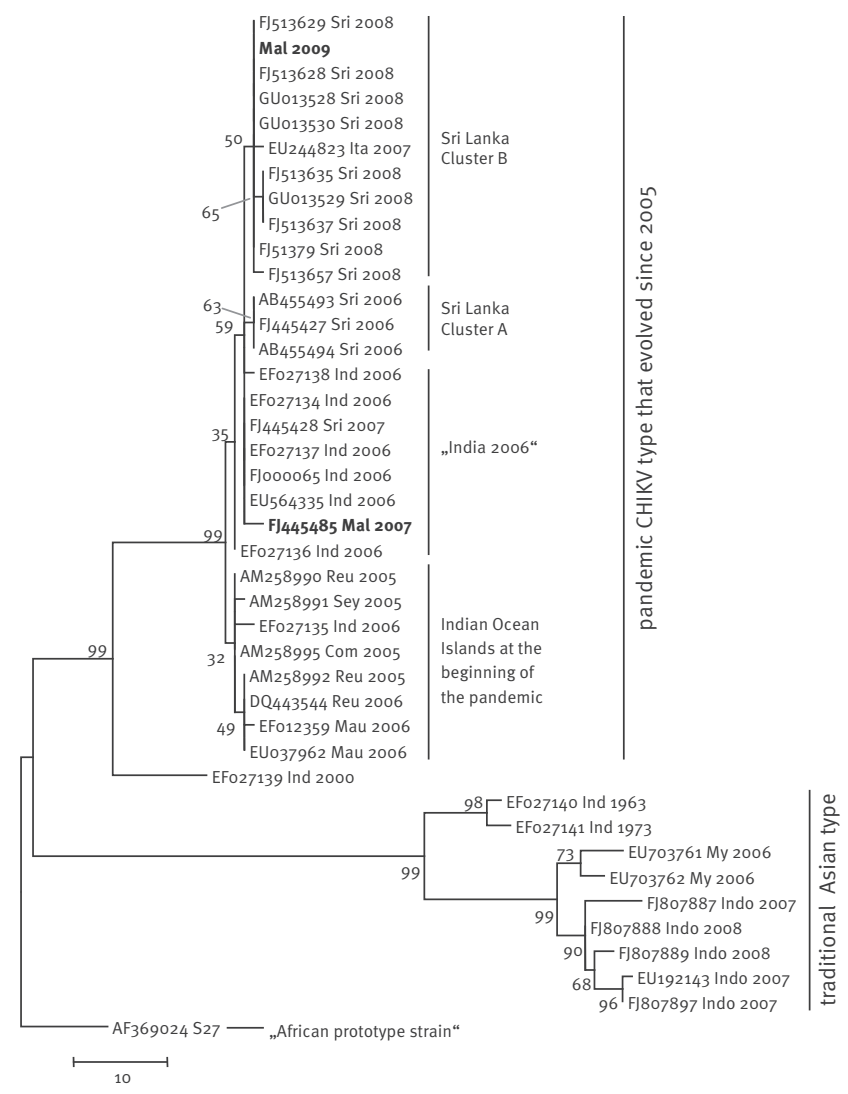

Sequence data are provided with their accession number, country and year. The term Cluster A and B for sequence data from Sri Lanka is adapted from [10]. Please note that the only available CHIKV E1 sequence from the Maldives from 2007 clusters together with CHIKV from India from 2006, while the CHIKV reported here is part of the Cluster B from Sri Lanka in 2008. Sri = Sri Lanka, Mal = Maldives, Ita = Italy (imported from India in 2007), Ind = India, Reu = Reunion, Sey = Seychelles, Com = Comores, Mau = Mauritius, My = Malaysia, Indo = Indonesia. The percentage of replicate trees in which the associated taxa clustered together in the bootstrap test (100 replicates) are shown next to the branches. The branch lengths are informative (bar length corresponds to 10 nt- differences)
It will be seen in the near future whether more cases of chikungunya fever will be reported for the Maldives, but we feel that this is already an issue in travel medicine although the German Robert Koch Institute reported only three chikungunya fever cases in returning travellers from the Maldives in 2009 (two of which we describe here). A crucial question concerning the current global situation on chikungunya fever is the adaptation of the pandemic CHIKV strain to Ae. albopictus. Aedes aegypti has been long known to occur on several islands of the Maldives and seems to be the predominant vector on Malé itself while Ae. albopictus has established foci on other islands where it seems to be the main mosquito vector species [5]. We do not know which Aedes species has infected the German tourists, but we do know that the A226V mutation is suggestive for Ae. albopictus as the vector. This particular mosquito is present in many areas around the Mediterranean Sea and was responsible for a CHIKV outbreak in Italy in 2007 resulting in more than 300 cases $[12,13]$. With a continuing circulation of CHIKV in major tourist destinations in Asia and Africa, imported cases of chikungunya fever will also be seen in Europe and North America. In countries were Ae. albopictus is abundant, returning viraemic tourists could cause smaller outbreaks.

\section{Acknowledgements}

Part of this work was supported by the Federal Ministry of Education and Research (BMBF) grant $01 \mathrm{KI} 0712$ to MP and GD as part of the network "Emerging arthropod-borne viral infections in Germany". The technical assistance of Nadine Roßner is gratefully acknowledged.

\section{References}

1. Powers $\mathrm{AM}$, Logue $\mathrm{CH}$. Changing patterns of Chi-akungunya virus: re-emergence of a zoonotic arbovirus. J Gen Virol. 2007;88(9):2363-77.

2. Staples JE, Breiman RF, Powers AM. Chikungunya fever: an epidemiological review of a re-emerging infectious disease. Clin Infect Dis. 2009;49(6):942-8.

3. Schuffenecker I, Iteman I, Michault A, Murri S, Frangeul L, Vaney MC, et al. Genome micro evolution of chikungunya viruses causing the Indian Ocean outreak. PLoS Med. 2006;3(7):e263.

4. Tsetsarkin KA, Vanlandingham DL, McGee CE, Higgs S. A single mutation in chikungunya virus affects vector specificity and epidemic potential. PloS Pathog. 2007;3(12):e201.

5. Yoosuf AA, Shiham I, Mohamed AJ, Ali G, Luna IM, Pandav R, et al. First report of chikungunya from the Maldives. Trans R Soc Trop Med Hyg. 2009;103(2):192-6.

6. Ng LC, Tan LK, Tan CH, Tan SS, Hapuarachchi HC, Pok KY, et al. Entomologic and virologic investigation of chikungunya, Singapore. Emerg Infect Dis. 2009;15(8):1243-9.

7. Acute febrile disease - Maldives: (Laamu Atoll) Request for information, 13 Jan 2009. In:ProMED-Mail-mail [online]. Boston US: International Society for Infectious Diseases: 13 January 2009. Archive no. 20090114.0150:. Available from: http://www. promedmail.org/pls/apex/f?p=2400:1202:60109559749468 20::NO::F2400_P1202_CHECK_DISPLAY,F2400_P1202_PUB_ MAIL_ID:X,75589

8. Panning M, Grywna K, van Esbroeck M, Emmerich P, Drosten $C$. Chikungunya fever in travelers returning to Europe from the Indian Ocean region, 2006. Emerg Infect Dis. 2008;14(3):416-22.

9. Panning M, Hess M, Fischer W, Grywna K, Pfeffer M, Drosten C. Performance of the RealStar Chikungunya Virus Real-Time Reverse Transcription-PCR Kit. J Clin Microbiol. 2009;47(9):3014-6. 
10. Receveur M, Ezzedine K, Pistone T, Malvy D. Chikungunya infection in a French traveler returning from the Maldives, October, 2009. Euro Surveill. 2010; 15(8):pii=19494.

Available from: http://www.eurosurveillance.org/ViewArticle. aspx?Articleld $=19494$

11. Hapuarachchi HC, Bandara KB, Sumanadasa SD, Hapugoda $M D$, Lai YL, Lee KS, et al. Re-emergence of chikungunya virus in South-east Asia: virological evidence from Sri Lanka and Singapore. J Gen Virol. 2010;91(Pf 4):1067-76.

12. Angelini $P$, Macini $P$, Finarelli $A C$, Pol C, Venturelli C, Bellini R, Dottori M. Chikungunya epidemic outbreak in Emilia-Romagna (Italy) during summer 2007. Parassitologia. 2008;50(1-2):97-8.

13. Bonilauri P, Bellini R, Calzolari M, Angelini R, Venturi L,

Fallacara F, et al. Chikungunya virus in Aedes albopictus, Italy. Emerg Infect Dis. 2008;14(5):852-4. 